\title{
PENGUKURAN GREENSHIP NEW BUILDING VER. 1.2 PADA BANGUNAN BARU RUMAH ATSIRI INDONESIA (FINAL ASSESSMENT)
}

\section{Irfan Ardhiansyah}

Program Studi Arsitektur Fakultas Teknik Universitas Muhammadiyah Surakarta e-mail irfanardhiansyah97@gmail.com

\section{Ronim Azizah}

Program Studi Arsitektur Fakultas Teknik Universitas Muhammadiyah Surakarta e-mail ronimazizah@gmail.com

\begin{abstract}
ABSTRAK
Green Building merupakan salah satu gagasan solutif untuk mengurangi dampak isu pemanasan global di era industri saat ini, sehingga menjadi tuntutan untuk diterapkan dalam desain arsitektur. Setidaknya perencanaan dan perancangaan dengan gagasan green building mampu merubah iklim mikro menjadi lebih baik. Di lingkup Indonesia, green building tengah menjadi tren dalam perancangan desain arsitektur yang beriringan dengan tumbuhnya kesadaran terhadap sertifikasi bangunan hijau oleh organisasi non-profit Green Building Council Indonesia (GBCl). Penelitian ini bertujuan untuk menilai berdasarkan standar bangunan hijau sebuah bangunan bersejarah di Tawangmangu yang telah dikonservasi dengan konsep optimal, efisien dan fungsional, yakni Rumah Atsiri Indonesia. Penelitian ini menerapakan metode kuantitatif dan kualitatif dengan menggunakan paramater Greenship New Building ver. 1.2 yang telah disediakan oleh $\mathrm{GBCl}$. Hasil penilaian yang telah dilakukan untuk setiap kategori adalah, Tepat Guna Lahan (ASD: 10 poin), Konservasi Energi (EEC: 3 poin), Konservasi Air (WAC: 3 poin), Siklus Material (MRC: 7 poin), Kenyamanan dalam Ruang (IHC: 3 poin), dan Manajemen lingkungan (BEM: 0 poin), sehingga total keseluruhan poin yang didapatkan Rumah Atsiri Indonesia adalah 26 poin. Hasil penelitian ini menunjukan bahwa gedung baru di kawasan Rumah Atsiri Indonesia belum layak dinyatakan sebagai green building karena belum memenuhi poin minimal yang disyaratkan Green Building Council Indonesia (GBCI).
\end{abstract}

KATA KUNCI: Green Building, Greenship, Rumah Atsiri Indonesia

\section{PENDAHULUAN}

Arsitektur dan teknologi merupakan dua hal yang tidak terpisahkan. Seiring zaman, arsitektur tidak hanya sebatas menekankan pada bentuk fisik yang menitikberatkan aspek estetika, tetapi juga harus memperhatikan terkait dampak pembangunan arsitektur terhadap lingkungan hidup.

Pada masa kini terdapat arus baru dalam perkembangan arsitektur disebabkan tumbuhnya kesadaran perancang terhadap lingkungan hidup yang memunculkan konsep arsitektur hijau. Berdasarkan konsep ini, arsitek sebagai perencana dan perancang dituntut untuk mendesain arsitektur yang memperhatikan aspek lingkungan hidup dengan menerapkan prinsip hemat energi dan meminimalisir polusi yang dihasilkan bangunan.

\section{TINJAUAN PUSTAKA}

\section{Arsitektur Hijau}

Arsitektur hijau adalah arsitektur yang ramah lingkungan. Menurut Thaib (2010: 36), penerapan arsitektur hijau bertujuan untuk menjadikan lingkungan lebih bermanfaat bagi generasi masa depan mempertimbangkan berbagai aspek sebelum melakukan eksplorasi terhadap lingkungan.

\section{Bangunan Hijau}

Bangunan hijau merupakan bangunan yang memenuhi persyaratan berdasarkan kinerja yang terukur dalam aspek penghematan air, energi, dan sumber daya lainnya. Salah satu syarat dan perhitungan yang terukur untuk menilai bangunan hijau di Indonesia disebut dengan Greenship yang dilakukan oleh Green Building Council Indonesia (GBCl) yang telah tergabung dalam World Green Building Council (WGBC) bersama 37 negara lainnya. Greenship merupakan sistem pengukuran bangunan hijau di Indonesia yang berbeda dengan negaranegara lainnya dengan tolak ukur dan nama tersendiri.

Sistem penilaian Greenship New Building Version 1.2 dijabarkan menjadi 6 kategori dengan 8 total kriteria prasyarat, 37 kriteria kredit, dan 1 kriteria bonus. 6 kategori dalam evaluasi penilaian Greenship New Building version 1.2 terdri dari:

1. Tepat Guna Lahan (Appropriate Site Development/ASD)

2. Efisiensi dan Konservasi Energi (Energy Effiency and Conservation/ EEC)

3. Konservasi Air (Water Conservation/WAC) 
4. Sumber dan Siklus Material (Material Resources and Cycle/ MRC)

5. Kesehatan dan Kenyamanan dalam Ruang (Indoor Health and Comfort/ IHC).

6. Manajemen Lingkungan Bangunan (Building Environtment Management/ BEM)

Table 1. Kriteria Tolak Ukur Greenship New Building version 1.2

\begin{tabular}{ccccc}
\hline \multirow{2}{*}{ Kategori } & \multicolumn{3}{c}{ Kriteria } & Total \\
\cline { 2 - 4 } & Prasyarat & Kredit & Bonus & \\
\hline ASD & 1 & 7 & & 8 \\
\hline EEC & 2 & 4 & 1 & 7 \\
\hline WAC & 2 & 6 & & 8 \\
\hline MRC & 1 & 6 & & 7 \\
\hline IHC & 1 & 7 & & 8 \\
\hline BEM & 1 & 7 & & 8 \\
\hline Total Poin & $\mathbf{8}$ & $\mathbf{3 7}$ & $\mathbf{1}$ & $\mathbf{4 6}$ \\
\hline
\end{tabular}

(Sumber: GBC Indonesia, 2013)

Kriteria kredit memiliki poin tertentu yang apabila poin tersebut mampu dicapai sesuai dengan total poin minimum yang diisyaratkan $\mathrm{GBCl}$, suatu gedung mendapatkan sertifikasi sesuai standar yang mengacu pada Greenship New Bulding version 1.1 seperti pada tabel berikut:

Table 2. Tingkat Predikat Greenship New Building version 1.1

\begin{tabular}{ccc}
\hline Predikat & Minimum Poin & $\begin{array}{c}\text { Poin yang } \\
\text { didapatkan (\%) }\end{array}$ \\
\hline Platinum & 74 & 73 \\
\hline Gold & 58 & 57 \\
\hline Silver & 47 & 46 \\
\hline Bronze & 35 & 35 \\
\hline
\end{tabular}

(Sumber : GBC Indonesia, 2013)

\section{METODE PENELITIAN}

Penelitian ini menggabungkan antara metode kuantitatif dan kualitatif karena selain mengaitkan data-data yang telah diperoleh untuk melakukan analisis terhadap bangunan studi kasus, penelitian ini juga mengkaitkan hasil analisis terhadap parameter Greenship New Building dari GBCl. Hasil yang hendak dicapai dalam penelitian ini adalah mengetahui kriteria dan indeks bangunan Resto di kawasan Rumah Atsiri Indonesia berdasarkan parameter dari $\mathrm{GBCl}$.

\section{Pengumpulan Data}

Penelitian ini menerapkan teknik pengumpulan data sebagai berikut:

1. Observasi. Pengamatan dilakukan dengan cara mencatat secara sistematik beberapa unsur yang muncul dalam suatu gejala pada objek penelitian. Hasil akhir observasi dituliskan dalam bentuk laporan yang disusun dengan sistematis sesuai dengan aturan.
2. Wawancara. Pengambilan data dengan wawancara dilakukan secara langsung tatap muka maupun melalui email. Jawaban dari pihak narasumber akan direkam dan dirangkum oleh peneliti.

3. Dokumentasi. Pengambilan data dilakukan melalui media tertulis maupun media elektronik dari lembaga atau institusi terkait sebagai data pendukung.

\section{Analisa Data}

Teknik analisa data merupakan metode untuk mengurutkan, mengatur, mengkategorikan, dan memberi tanda/kode terhadap data untuk mengolah hasil penelitian guna menemukan suatu kesimpulan.

\section{Sintesis Data}

Melakukan identifikasi terhadap data greenship yang telah diolah dengan tujuan untuk menemukan hasil penelitian.

\section{HASIL DAN PEMBAHASAN}

\section{Gambaran Umum Rumah Atsiri Indonesia}

Rumah Atsiri Indonesia adalah salah satu proyek mercusuar yang dicanangkan oleh Presiden Ir. Soekarno bekerjasama dengan pemerintah Bulgaria yang digadang-gadang sebagai pabrik minyak atsiri "Citronella" terbesar di Asia pada masanya untuk memberdayakan serta menyejahterakan masyarakat Indonesia. Namun karena tidak berjalan sesuai rencana, pabrik ini akhirnya terbengkalai saat pembangunan mencapai $80 \%$ karena tidak kondusifnya kondisi di negara Indonesia saat itu. Pabrik minyak atsiri sempat beberapa kali beralih kepemilikan, hingga akhirnya pada september 2015 kepemilikan beralih ke PT. Rumah Atsiri Indonesia.

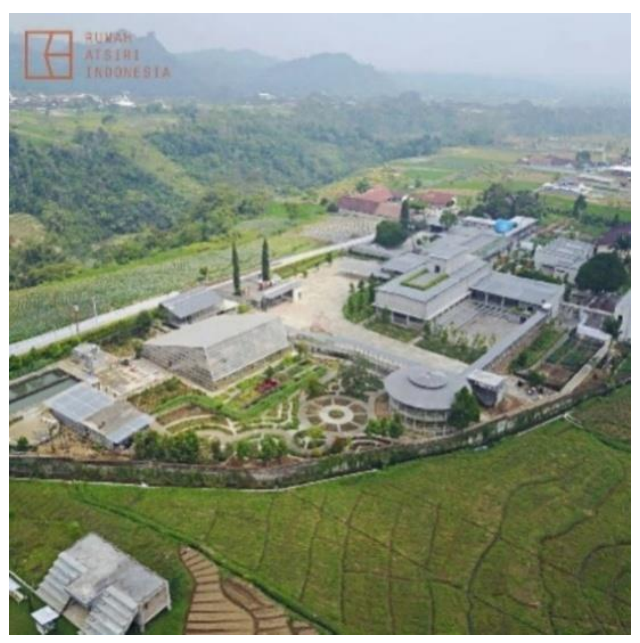

Gambar 1. Kawasan Rumah Atsiri Indonesia (Sumber : rumahatsiri.com, 2018)

\section{Resto Rumah Atsiri}


Resto di kawasan Rumah Atsiri merupakan fasilitas penunjang kegiatan wisata. Wisatawan yang berkunjung ke Rumah Atsiri dapat menukarkan voucher masuk dengan makan dan minum di resto ini yang berstatus sebagai bangunaan baru di kawasan Rumah Atsiri dan telah beroperasi sesuai dengan fungsinya saat penelitian ini dilakukan.
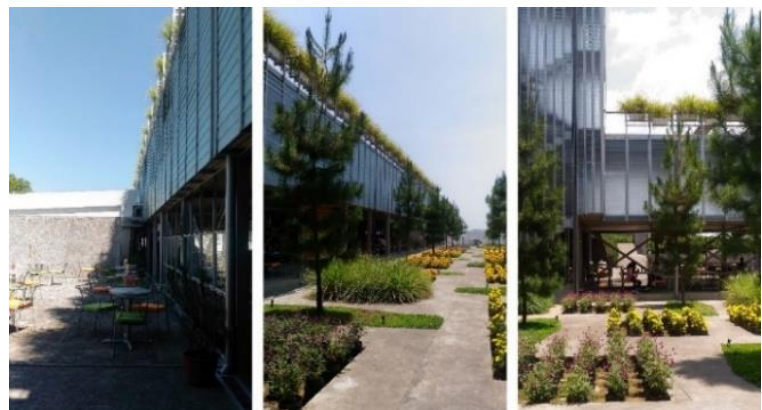

Gambar 2. Resto Rumah Atsiri

(Sumber : Dokumentasi Penulis, 2018)

\section{Identifikasi Studi Kasus}

Untuk dapat dilakukan penilaian terhadap bangunan Resto di kawasan Rumah Atsiri Indonesia harus memenuhi kelayakan yang ditetapkan oleh pihak $\mathrm{GBCl}$, yakni sebagai berikut:

1. Gedung memiliki luas minimum $2.500 \mathrm{~m}^{2}$

2. Kesediaan data gedung untuk diakses GBC Indonesia terkait proses sertifikasi.

3. Fungsi gedung menyesuaikan dengan perubahan lahan berdasarkan RTRW Karanganyar.

4. Kepemilikan AMDAL dan/atau rencana Upaya Pengelolaan Lingkungan (UPL)/Upaya Pemantauan Lingkungan (UPL).

5. Belum adanya kesesuaian gedung terhadap standar keselamatan untuk kebakaran.

6. Kesesuaian perhitungan struktur gedung terhadap standar ketahanan gempa.

7. Kesesuaian gedung terhadap standar aksesibilitas untuk penyandang difabel.

Dari 7 Syarat kelayakan yang telah dijabarkan di atas, bangunan Resto di kawasan Rumah Atsiri Indonesia layak untuk dilanjutkan ke tahap identifikasi untuk menjabarkan setiap kategori dan kriteria yang telah ditentukan oleh pihak $\mathrm{GBCl}$, sebagai berikut:

\section{Appropriate Site Development (ASD)/ Tepat Guna Lahan}

Table 3. Kategori dan Kriteria Tepat Guna Lahan/ASD

\begin{tabular}{|l|l|c|c|c|}
\hline \multicolumn{2}{|c|}{ Kategori dan Kriteria } & $\begin{array}{c}\text { Nilai } \\
\text { Maksi } \\
\text { mum }\end{array}$ & $\begin{array}{c}\text { Nilai } \\
\text { Dida } \\
\text { patkan }\end{array}$ & $\begin{array}{c}\text { Keterangan } \\
\text { Kategori }\end{array}$ \\
\hline ASD P & $\begin{array}{l}\text { Area Dasar } \\
\text { Hijau (Basic } \\
\text { Green Area) }\end{array}$ & P & & \\
\hline
\end{tabular}

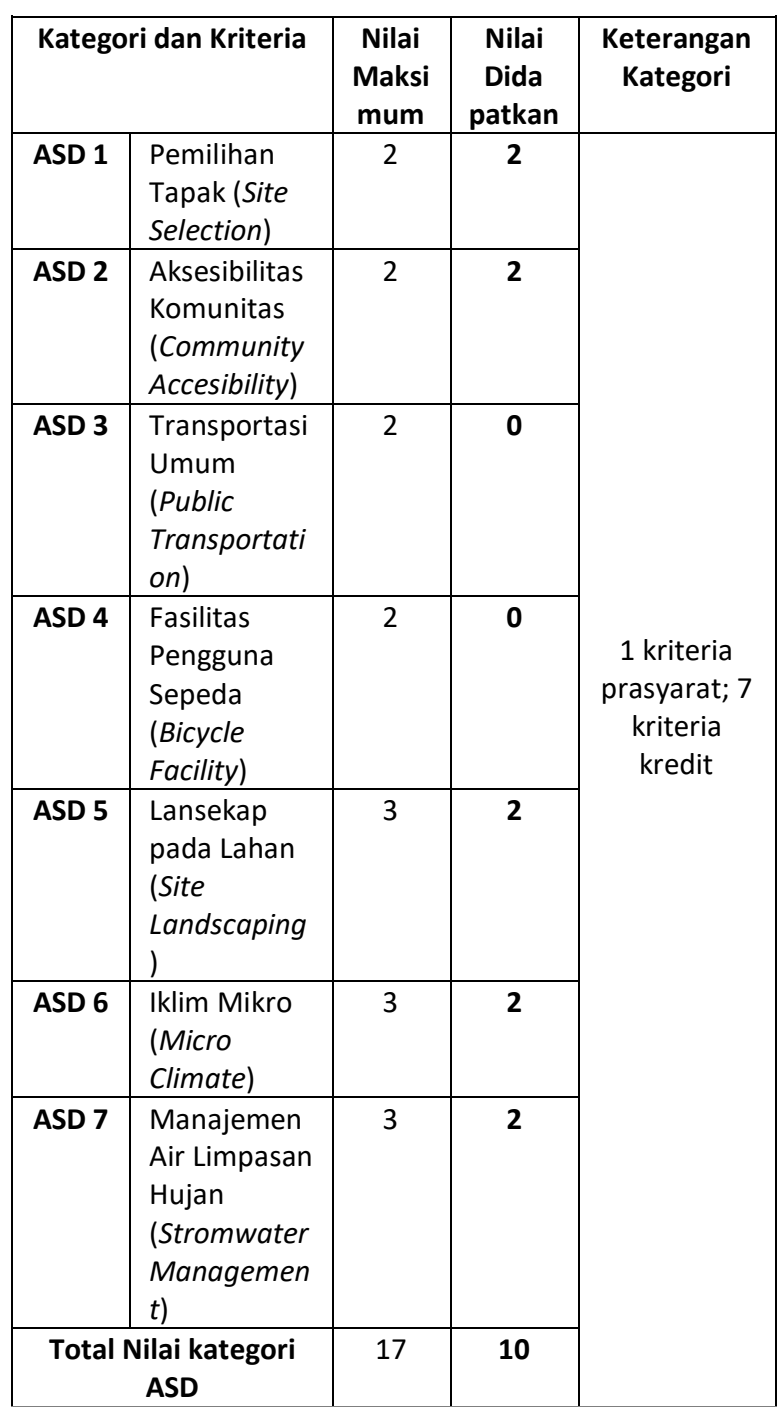

(Sumber: Analisa, 2018)

Penjelasan:

ASD P : Standart persyaratan dianggap ada.

ASD 1 : Pemilihan Tapak

Poin 1.A : Terdapat 8 dari 12 prasarana kota.

Poin 2 : Bangunan ini hasil dari revitalisasi dan berdiri di atas lahan negatif yang tidak digunakan kembali karena sudah lama terbengkalai dan berkalikali berpindah tangan kepemilikannya.

\section{ASD 2 : Aksesibilitas Komunitas}

Poin 1.A : Terdapat 7 jenis fasilitas umum dalam jarak pencapaian jalan utama sejauh $1.500 \mathrm{~m}$ dari tapak.

Poin 2 : Terdapat akses untuk pejalan kaki menuju minimal ke 3 tempat fasilitas umum sejauh 300 m jarak pencapaian dengan berjalan kaki.

\section{ASD 3 : Transportasi Umum}

Poin 1.A: Tidak terdapat halte atau transportasi umum dalam jangkauan $300 \mathrm{~m}$ untuk saat ini.

Poin 2 : Tidak ada jalur khusus pedestrian yang terdapat di dalam area gedung untuk menuju ke transportasi umum terdekat.

ASD 4 : Fasilitas Pengguna Sepeda 
Poin 1 : Tidak terdapatnya tempat parkir sepeda, karena lebih difokuskan untuk mewadahi parkir motor, mobil, dan bus.

Poin 2 :Tidak terdapat shower untuk setiap 10 parkir sepeda.

ASD 5 : Lansekap Pada Lahan

Poin 1A : Adanya area lansekap berupa vegetasi softscape yang bebas dari bangunan taman (hardscape) sekitar 40\%.

Poin 2 : Terdapat banyak tanaman lokal yang dibudidayakan lebih dari $60 \%$, terutama tanamantanaman Atsiri, dan sebagian tanaman impor adalah lavender.

ASD 6 : Iklim Mikro

Poin 1A dan 2 : Menurut data, nilai Albedo material beton yang digunakan pada atap restaurant Rumah Atsiri adalah 0.10-0.35, sehingga memenuhi nilai minimal 0,3 dari yang disyaratkan.

Poin $3 \mathrm{~A}$ : Adanya pelindung dari panas pada desain lansekap vegetasi (softscape) pada sirkulasi utama pejalan kaki.

\section{ASD 7 : Manajemen Air}

Poin $1 \mathrm{~A}$ : Beban volume air hujan $50 \%$ dialirkan ke dalam kolam ikan dan sebagian diserap langsung ke tanah dan jatuh ke material perkerasan yang mengalir ke sungai melalui saluran drainase.

Poin 2 : Terdapat banyak resapan tanah. Dikarenakan berada di puncak, kawasan tidak memiliki beban banjir lingkungan.

Poin 3 : Tidak terdapatnya teknologi yang mampu mengurangi debit limpasan air hujan, dan masih menggunakan sistem gravitasi

2. Energy Efficiency and Conservation (EEC)/ Efisiensi dan Konservasi Energi

Table 4. Kategori dan Kriteria Efisiensi dan Konservasi

\begin{tabular}{|c|c|c|c|c|}
\hline \multicolumn{5}{|c|}{ Energi/EEC } \\
\hline \multicolumn{2}{|c|}{ Kategori dan Kriteria } & \multirow{2}{*}{$\begin{array}{c}\begin{array}{c}\text { Nilai } \\
\text { Maksim } \\
\text { um }\end{array} \\
P\end{array}$} & \multirow{2}{*}{$\begin{array}{c}\text { Nilai } \\
\text { Dida } \\
\text { patkan }\end{array}$} & Keterangan \\
\hline $\begin{array}{c}\text { EEC } \\
\text { P1 }\end{array}$ & $\begin{array}{l}\text { Pemasangan } \\
\text { Sub-Meter } \\
\text { (Electrical Sub } \\
\text { Metering) }\end{array}$ & & & \multirow{4}{*}{$\begin{array}{l}1 \text { kriteria } \\
\text { prasyarat; } 5 \\
\text { kriteria } \\
\text { kredit }\end{array}$} \\
\hline $\begin{array}{c}\text { EEC } \\
\text { P2 }\end{array}$ & $\begin{array}{l}\text { Perhitungan } \\
\text { OTTV (OTTV } \\
\text { Calculation) }\end{array}$ & $P$ & 0 & \\
\hline $\begin{array}{c}\text { EEC } \\
1\end{array}$ & $\begin{array}{l}\text { Langkah } \\
\text { Penghematan } \\
\text { Energi (Energy } \\
\text { Efficiency } \\
\text { Measures) }\end{array}$ & 20 & 0 & \\
\hline $\begin{array}{c}\text { EEC } \\
2\end{array}$ & $\begin{array}{l}\text { Pencahayaan } \\
\text { Alami } \\
\text { (Ventilation) }\end{array}$ & 4 & 2 & \\
\hline
\end{tabular}

\begin{tabular}{|c|c|c|c|c|}
\hline \multicolumn{2}{|c|}{ Kategori dan Kriteria } & \multirow{2}{*}{$\begin{array}{c}\begin{array}{c}\text { Nilai } \\
\text { Maksim } \\
\text { um }\end{array} \\
1\end{array}$} & \multirow{2}{*}{\begin{tabular}{|c|}
$\begin{array}{c}\text { Nilai } \\
\text { Dida } \\
\text { patkan }\end{array}$ \\
1 \\
\end{tabular}} & \multirow{3}{*}{$\begin{array}{c}\begin{array}{c}\text { Keterangan } \\
\text { Kategori }\end{array} \\
\end{array}$} \\
\hline $\begin{array}{c}\text { EEC } \\
3\end{array}$ & $\begin{array}{l}\text { Ventilasi } \\
\text { (Natural } \\
\text { Lighting) }\end{array}$ & & & \\
\hline $\begin{array}{c}\text { EEC } \\
4\end{array}$ & $\begin{array}{l}\text { Pengaruh } \\
\text { Perubahan } \\
\text { Ikllim (Site } \\
\text { Landscaping) }\end{array}$ & 1 & 0 & \\
\hline $\begin{array}{c}\text { EEC } \\
5\end{array}$ & $\begin{array}{l}\text { Energi } \\
\text { Terbarukan } \\
\text { Dalam Tapak } \\
\text { (On Site } \\
\text { Renewable } \\
\text { Energy) }\end{array}$ & 5 & 0 & \\
\hline \multicolumn{2}{|c|}{$\begin{array}{l}\text { Total Nilai kategori } \\
\text { EEC }\end{array}$} & 26 & 3 & \\
\hline
\end{tabular}

(Sumber: Analisa, 2018)

\section{Penjelasan:}

EEC P1 : Terdapat KWH meter untuk mengukur konsumsi listrik.

EEC P1 : Perhitungan OTTV tidak dijadikan prasyarat karena alasan keterbatasan pengetahuan dan alat yang digunakan mengenai OTTV, dan tidak terdapat perhitungan OTTV dari pihak perencana.

\section{EEC 1 : Efisiensi Dan Konservasi Energi}

Poin 1 : Pengelolaan energi pada Rumah Atsiri Indonesia tidak menggunakan energy modeling software.

\section{EEC 2 : Pencahayaan Alami}

Poin 1 : Penggunaan cahaya alami lebih dari $30 \%$ dari luas bangunan restoran karena bukaan dibuat selebar dan sepanjang gedung.

Poin 2 : Tidak adanya lux sensor pada bangunan restoran Rumah Atsiri.

\section{EEC 3 : Ventilasi}

Poin 1 : Tidak menggunakan AC sama sekali pada ruang WC dan tangga. Semua area memanfaatkan semaksimal mungkin ventilasi alami.

\section{EEC 4 : Pengaruh Perubahan Iklim}

Poin 1 : Tidak terdapat perhitungan pengurangan $\mathrm{CO} 2$.

EEC 5 : Pengaruh Perubahan Iklim

Poin 1 : Tidak menggunakan energi baru dan terbarukan. Semua listrik dipasok dari PLN.

\section{Water Conservation (WAC)/Konservasi Air}

Table 5. Konservasi Air/WAC

\begin{tabular}{|c|l|c|c|c|}
\hline \multicolumn{2}{|c|}{ Kategori dan Kriteria } & $\begin{array}{c}\text { Nilai } \\
\text { Maksi } \\
\text { mum }\end{array}$ & $\begin{array}{c}\text { Nilai } \\
\text { Dida } \\
\text { patkan }\end{array}$ & $\begin{array}{c}\text { Keterangan } \\
\text { Kategori }\end{array}$ \\
\hline $\begin{array}{c}\text { WAC } \\
\text { P1 }\end{array}$ & $\begin{array}{l}\text { Meteran Air } \\
\text { (Electrical Sub } \\
\text { Metering) }\end{array}$ & P & - & \\
\hline
\end{tabular}




\begin{tabular}{|c|c|c|c|c|}
\hline \multicolumn{2}{|c|}{ Kategori dan Kriteria } & \multirow{2}{*}{$\begin{array}{c}\begin{array}{c}\text { Nilai } \\
\text { Maksi } \\
\text { mum }\end{array} \\
P\end{array}$} & \multirow{2}{*}{$\begin{array}{c}\text { Nilai } \\
\text { Dida } \\
\text { patkan }\end{array}$} & \multirow{2}{*}{$\begin{array}{c}\text { Keterangan } \\
\text { Kategori }\end{array}$} \\
\hline $\begin{array}{c}\text { WAC } \\
\text { P2 }\end{array}$ & $\begin{array}{l}\text { Perhitungan } \\
\text { Penggunaan } \\
\text { Air (OTTV } \\
\text { Calculation) }\end{array}$ & & & \\
\hline $\begin{array}{c}\text { WAC } \\
1\end{array}$ & $\begin{array}{l}\text { Pengurangan } \\
\text { Penggunaan } \\
\text { Air (Water } \\
\text { Use } \\
\text { Reduction) }\end{array}$ & 8 & 0 & \multirow{7}{*}{$\begin{array}{c}2 \text { kriteria } \\
\text { prasyarat; } 6 \\
\text { kriteria } \\
\text { kredit }\end{array}$} \\
\hline $\begin{array}{c}\text { WAC } \\
2\end{array}$ & $\begin{array}{l}\text { Fitur Air } \\
\text { (Water } \\
\text { Fixtures) }\end{array}$ & 3 & 2 & \\
\hline $\begin{array}{c}\text { WAC } \\
3\end{array}$ & $\begin{array}{l}\text { Daur Ulang } \\
\text { Air (Water } \\
\text { Recycling) }\end{array}$ & 3 & 0 & \\
\hline $\begin{array}{c}\text { WAC } \\
4\end{array}$ & $\begin{array}{l}\text { Sumber Air } \\
\text { Alternatif } \\
\text { (Alternative } \\
\text { Water } \\
\text { Resource) } \\
\end{array}$ & 2 & 0 & \\
\hline $\begin{array}{l}\text { WAC } \\
5\end{array}$ & $\begin{array}{l}\text { Penampungan } \\
\text { Air Hujan } \\
\text { (Rainwater } \\
\text { Harvesting) } \\
\end{array}$ & 3 & 0 & \\
\hline $\begin{array}{c}\text { WAC } \\
6\end{array}$ & $\begin{array}{l}\text { Efisiensi } \\
\text { Penggunaan } \\
\text { Air Lansekap } \\
\text { (Water } \\
\text { Efficiency } \\
\text { Landscaping) }\end{array}$ & 2 & 1 & \\
\hline Total & $\begin{array}{l}\text { Nilai kategori } \\
\text { WAC }\end{array}$ & 21 & 3 & \\
\hline
\end{tabular}

(Sumber : Analisa, 2018)

Penjelasan:

WAC P1 : Terdapat meteran air pada setiap keluaran sumber air bersih.

WAC P2 : Tidak menggunakan worksheet air standar $\mathrm{GBCl}$.

WAC 1 : Pengurangan Penggunaan Air

Poin 1 : Konsumsi air bersih dengan sumber primer masih diatas $80 \%$.

WAC 2 : Fitur Air

Poin 1 : Penggunaan fitur air sesuai kapasitas buangan sebesar $50 \%$ dari ottal pengadaan produk fitur air.

WAC 3 : Daur Ulang Air

Poin 1 : Tidak adanya air yang berasal dari sumber daur ulang yang berasal dari pemanfaatan limbah gedung.

WAC 4 : Sumber Air Alternatif

Poin 1 : Tidak menggunakan air alternatif yang diproses.

\section{WAC 5 : Penampungan Air Hujan}

Poin 1 : Tidak terdapatnya instalasi tangki penampungan air hujan.
WAC 6 : Efisiensi Penggunaan Air Lansekap

Poin 1 : Air yang digunakan untuk irigasi memanfaatkan sumber dari sungai. Tidak semua menggunakan dari sumber air tanah.

\section{Material Resources and Cycle (MRC)/ Sumber dan Siklus Material}

Table 6. Sumber dan Siklus Material/MRC

\begin{tabular}{|c|c|c|c|c|}
\hline \multicolumn{2}{|c|}{ Kategori dan Kriteria } & \multirow{2}{*}{$\begin{array}{c}\begin{array}{c}\text { Nilai } \\
\text { Maksi } \\
\text { mum }\end{array} \\
P\end{array}$} & \multirow{2}{*}{$\begin{array}{c}\text { Nilai } \\
\begin{array}{c}\text { Didapat } \\
\text { kan }\end{array} \\
-\end{array}$} & \multirow{3}{*}{$\begin{array}{c}\text { Keterangar } \\
\text { Kategori }\end{array}$} \\
\hline $\begin{array}{c}\text { MRC } \\
\mathbf{P}\end{array}$ & $\begin{array}{l}\text { Refrigeran } \\
\text { Fundamental } \\
\text { (Fundamental } \\
\text { Refrigerant) }\end{array}$ & & & \\
\hline $\begin{array}{c}\text { MRC } \\
1\end{array}$ & $\begin{array}{l}\text { Penggunaan } \\
\text { Gedung dan } \\
\text { Material } \\
\text { (Building and } \\
\text { Material } \\
\text { Resuse) }\end{array}$ & 2 & - & \\
\hline $\begin{array}{c}\mathrm{MRC} \\
2\end{array}$ & $\begin{array}{l}\text { Material } \\
\text { Ramah } \\
\text { Lingkungan } \\
\text { (Water Use } \\
\text { Reduction) }\end{array}$ & 3 & 0 & \multirow{6}{*}{$\begin{array}{c}1 \text { kriteria } \\
\text { prasyarat; } \\
6 \text { kriteria } \\
\text { kredit }\end{array}$} \\
\hline $\begin{array}{c}\text { MRC } \\
3\end{array}$ & $\begin{array}{l}\text { Penggunaan } \\
\text { Refrigeran } \\
\text { tanpa ODP } \\
\text { (Non ODS } \\
\text { Usage) }\end{array}$ & 2 & 2 & \\
\hline $\begin{array}{c}\text { MRC } \\
4\end{array}$ & $\begin{array}{l}\text { Kayu } \\
\text { Bersertifikat } \\
\text { (Certifed } \\
\text { Wood) }\end{array}$ & 2 & 2 & \\
\hline $\begin{array}{c}\text { MRC } \\
5\end{array}$ & $\begin{array}{l}\text { Material } \\
\text { Fabrikasi } \\
\text { (Prefab } \\
\text { Material) }\end{array}$ & 3 & 2 & \\
\hline $\begin{array}{c}\text { MRC } \\
6\end{array}$ & $\begin{array}{l}\text { Material } \\
\text { Regional } \\
\text { (Regional } \\
\text { Material) }\end{array}$ & 2 & 1 & \\
\hline Tota & $\begin{array}{l}\text { Nilai kategori } \\
\text { MRC }\end{array}$ & 14 & 7 & \\
\hline
\end{tabular}

(Sumber : Analisa, 2018)

\section{Penjelasan:}

MRCP : Tidak ditemukannya penggunaan CFC sebagai refrigran.

MRC 1 : Penggunaan Gedung Dan Material

Poin 1 : Tidak ditemukanya material bekas pada bangunan.

MRC 2 : Material Ramah Lingkungan

Poin 1 : Tidak menggunakan material yang memiliki sertifikat sistem manajemen lingkungan pada proses produksinya. 
Poin 2 : Tidak menggunakan material hasil proses daur ulang.

Poin 3 : Tidak menggunakan material yang bahan baku utamanya dari sumber terbarukan.

\section{MRC 3 : Penggunaan Refrigeran Tanpa Odp}

Poin1 : Tidak ditemukan sistem pendingin yang berpotensi merusak ozon.

\section{MRC 4 : Kayu Bersertifikat}

Poin 1 : Menggunakan material kayu bersertifikat legal dan terbebas dari perdagangan kayu ilegal untuk keseluruhan material kayu.

Poin 2 : Menggunakan kayu bersertifikasi dari pihak FSC.

\section{MRC 5 : Material Fabrikasi}

Poin 1 :Menggunakan material modular/fabrikasi berupa material baja, besi, dan kaca.

\section{MRC 6 : Material Regional}

Poin 1 : Tidak menggunakan material lokasi asal bahan baku utama dalam radius $1.000 \mathrm{~km}$.

Poin 2 : Penggunaan material asal bahan baku utama dan fabrikasi berada dalam wilayah Republik Indonesia.

\section{Indoor Health and Comfort (IHC)/Kesehatan dan Kenyamanan dalam Ruang}

Table 7. Kesehatan dan Kenyamanan dalam Ruang - IHC

\begin{tabular}{|c|c|c|c|c|}
\hline \multicolumn{2}{|c|}{$\begin{array}{l}\text { Kategori dan } \\
\text { Kriteria }\end{array}$} & $\begin{array}{c}\text { Nilai } \\
\text { Maksi }\end{array}$ & $\begin{array}{l}\text { Nilai } \\
\text { Dida }\end{array}$ & $\begin{array}{c}\text { Keterangan } \\
\text { Kategori }\end{array}$ \\
\hline $\begin{array}{l}\text { IH } \\
\text { C P }\end{array}$ & $\begin{array}{l}\text { Refrigeran } \\
\text { Fundamental } \\
\text { (Fundamental } \\
\text { Refrigerant) }\end{array}$ & $P$ & - & \\
\hline $\begin{array}{l}\mathrm{IH} \\
\mathrm{C} 1\end{array}$ & $\begin{array}{l}\text { Pemantauan } \\
\text { Kadar } \mathrm{CO}_{2} \\
\left(\mathrm{CO}_{2}\right. \\
\text { Monitoring })\end{array}$ & 1 & - & \\
\hline $\begin{array}{l}\mathrm{IH} \\
\mathrm{C} 2\end{array}$ & $\begin{array}{l}\text { Kendali Asap } \\
\text { Rokok di } \\
\text { Lingkungan } \\
\text { (Environment } \\
\text { al Tobacco } \\
\text { Smoke } \\
\text { Control) }\end{array}$ & 2 & 0 & $\begin{array}{c}1 \text { kriteria } \\
\text { prasyarat; } 7\end{array}$ \\
\hline $\begin{array}{l}\mathrm{IH} \\
\mathrm{C} 3\end{array}$ & $\begin{array}{l}\text { Polutan Kimia } \\
\text { (Chemical } \\
\text { Pollutant) }\end{array}$ & 3 & 1 & $\begin{array}{c}\text { kriteria } \\
\text { kredit }\end{array}$ \\
\hline $\begin{array}{l}\mathrm{IH} \\
\mathrm{C} 4\end{array}$ & $\begin{array}{l}\text { Pemandanga } \\
\mathrm{n} \text { ke luar } \\
\text { Gedung } \\
\text { (Outside } \\
\text { View) }\end{array}$ & 1 & 0 & \\
\hline $\begin{array}{l}\mathrm{IH} \\
\mathrm{C} 5\end{array}$ & $\begin{array}{l}\text { Kenyamanan } \\
\text { Visual (Visual } \\
\text { Comfort) }\end{array}$ & 1 & 1 & \\
\hline $\begin{array}{l}\text { IH } \\
\text { C } 6\end{array}$ & $\begin{array}{l}\text { Kenyamanan } \\
\text { Thermal }\end{array}$ & 1 & 1 & \\
\hline
\end{tabular}

\begin{tabular}{|c|c|c|c|c|}
\hline \multicolumn{2}{|c|}{$\begin{array}{l}\text { Kategori dan } \\
\text { Kriteria }\end{array}$} & \multirow{2}{*}{$\begin{array}{l}\text { Nilai } \\
\text { Maksi } \\
\text { mum }\end{array}$} & \multirow{2}{*}{$\begin{array}{c}\text { Nilai } \\
\text { Dida } \\
\text { patkan }\end{array}$} & \multirow{2}{*}{$\begin{array}{c}\text { Keterangan } \\
\text { Kategori }\end{array}$} \\
\hline & $\begin{array}{l}\text { (Thermal } \\
\text { Comfort) }\end{array}$ & & & \\
\hline $\begin{array}{l}\mathrm{IH} \\
\mathrm{C} 7\end{array}$ & $\begin{array}{l}\text { Tingkat } \\
\text { Kebisingan } \\
\text { (Acoustic } \\
\text { Level) }\end{array}$ & 1 & 0 & \\
\hline \multicolumn{2}{|c|}{$\begin{array}{c}\text { Total Nilai kategori } \\
\text { IHC }\end{array}$} & 10 & 3 & \\
\hline
\end{tabular}

(Sumber: Analisa, 2018)

\section{Penjelasan:}

IHC P : Adanya potensi introduksi udara luar.

IHC 1 : Pemantauan Kadar $\mathrm{CO}_{2}$

Poin 1 : Tidak ditemukan adanya kepadatan kurang kurang dari $2.3 \mathrm{~m}^{2} /$ orang.

IHC 2 : Kendali Asap Rokok Di Lingkungan

Poin 1 : Tidak memasang tanda dilarang merokok di seluruh area gedung.

IHC 3 : Polutan Kimia

Poin 1 : Tidak menggunakan cat dan coating yang mengandung VOCs rendah.

Poin 2 : Tidak menggunakan produk kayu komposit dan laminating adhesive.

Poin 3 : Menggunakan material lampu LED yang tidak memiliki kandungan merkuri.

IHC 4 : Pemandangan Keluar Gedung

Poin 1 : Kawasan memiliki pemandangan luar berupa perkebunan, sawah dan perbukitan tanpa adanya batasan transparan.

IHC 5 : Kenyamanan Visual

Poin 1 : Pada siang hari tidak menggunakan lampu. Lampu hanya digunakan pada malam hari sebagai spotlight.

IHC 6 : Kenyamanan Thermal

Poin 1 : Suhu luar pada siang hari berada pada kisaran $26^{\circ} \mathrm{C}$ sedangkan di dalam ruangan kisaran $24^{\circ} \mathrm{C}$.

IHC 7 : Tingkat Kebisingan

Poin 1 : Didapatkan rata-rata hasil perhitungan desibel belum memenuhi bunyi yang dianjurkan.

\section{Building Environtment Management (BEM)/Manajemen Lingkungan Bangunan}

Tabel 8.Manajemen Lingkungan Bangunan/BEM

\begin{tabular}{|c|l|c|c|c|}
\hline \multicolumn{2}{|c|}{ Kategori dan Kriteria } & $\begin{array}{c}\text { Nilai } \\
\text { Maksi } \\
\text { mum }\end{array}$ & $\begin{array}{c}\text { Nilai } \\
\text { Didap } \\
\text { atkan }\end{array}$ & $\begin{array}{c}\text { Keterangan } \\
\text { Kategori }\end{array}$ \\
\hline $\begin{array}{c}\text { BEM } \\
\text { P }\end{array}$ & $\begin{array}{l}\text { Refrigran } \\
\text { Fundamental } \\
\text { (Basic Waste } \\
\text { Management) }\end{array}$ & P & - & \\
\cline { 1 - 3 } BEM & $\begin{array}{l}\text { GP Sebagai } \\
\text { Anggota Tim } \\
\text { Proyek (GP as a }\end{array}$ & 1 & - & \\
\cline { 1 - 2 } & & & \\
\hline
\end{tabular}




\begin{tabular}{|c|c|c|c|c|}
\hline \multicolumn{2}{|c|}{ Kategori dan Kriteria } & \multirow{2}{*}{$\begin{array}{l}\text { Nilai } \\
\text { Maksi } \\
\text { mum } \\
\end{array}$} & \multirow{2}{*}{$\begin{array}{c}\text { Nilai } \\
\text { Didap } \\
\text { atkan }\end{array}$} & \multirow{3}{*}{$\begin{array}{c}\text { Keterangan } \\
\text { Kategori }\end{array}$} \\
\hline & $\begin{array}{l}\text { Member if } \\
\text { Project Team) }\end{array}$ & & & \\
\hline $\begin{array}{c}\text { BEM } \\
2\end{array}$ & $\begin{array}{l}\text { Polusi dari } \\
\text { Aktivitas } \\
\text { Konstruksi } \\
\text { (Pollution of } \\
\text { Construction } \\
\text { Activity) }\end{array}$ & 2 & 0 & \\
\hline $\begin{array}{c}\text { BEM } \\
3\end{array}$ & $\begin{array}{l}\text { Pengelolaan } \\
\text { Sampah Tingkat } \\
\text { Lanjut } \\
\text { (Advanced } \\
\text { Waste } \\
\text { Management) }\end{array}$ & 2 & 0 & \multirow{5}{*}{$\begin{array}{c}1 \text { kriteria } \\
\text { prasyarat; } 7 \\
\text { kriteria } \\
\text { kredit }\end{array}$} \\
\hline $\begin{array}{c}\text { BEM } \\
4\end{array}$ & $\begin{array}{l}\text { Sistem } \\
\text { Komisioning } \\
\text { yang Baik dan } \\
\text { Benar } \\
\text { (Proper } \\
\text { Commisioning) } \\
\end{array}$ & 3 & 0 & \\
\hline $\begin{array}{c}\text { BEM } \\
5\end{array}$ & $\begin{array}{l}\text { Penyerahan } \\
\text { Data Green } \\
\text { Building } \\
\text { (Green Building } \\
\text { Submissuib } \\
\text { Data) }\end{array}$ & 2 & 0 & \\
\hline $\begin{array}{c}\text { BEM } \\
6\end{array}$ & $\begin{array}{l}\text { Kesepakatan } \\
\text { dalam } \\
\text { Melakukan } \\
\text { Aktivitas Fit Out } \\
\text { (Fit Out } \\
\text { Agreement) }\end{array}$ & 1 & 0 & \\
\hline $\begin{array}{c}\text { BEM } \\
7\end{array}$ & $\begin{array}{l}\text { Survey } \\
\text { Pengguna } \\
\text { Gedung } \\
\text { (Occupant } \\
\text { Survey) }\end{array}$ & 1 & 0 & \\
\hline & $\begin{array}{l}\text { I Nilai kategori } \\
\text { ASD }\end{array}$ & 13 & 0 & \\
\hline
\end{tabular}

(Sumber: Analisa, 2018)

\section{Penjelasan:}

BEM P : Tidak ada fasilitas atau instalasi untuk memilah dan mengumpulkan sampah yang sejenis sampah rumah tangga.

\section{BEM 1 : GP Sebagai Anggota Tim Proyek}

Poin 1 : Tidak adanya keterlibatan seorang tenaga ahli bersertifikasi Greenship Professional (GP).

\section{BEM 2 : Polusi Dari Aktivitas Konstruksi}

Poin 1 : Tidak terdapat rencana manajemen sampah konstruksi limbah padat.

Poin 2 : Tidak terdapat rencana manajemen sampah konstruksi limbah cair.

BEM 3 : Pengelolaan Sampah Tingkat Lanjut

Poin 1 : Tidak mengolah limbah organik gedung secara mandiri.
Poin 2 : Tidak mengolah limbah anorganik gedung secara mandiri.

BEM 4 : Sistem Komisioning Yang Baik Dan Benar

Poin 1 : Tidak ada prosedur testing-commissioning sesuai petunjuk $\mathrm{GBCl}$.

Poin 2 : Tidak terdapat adjusting instrument yang terpasang pada saat konstruksi.

BEM 5 : Penyerahan Data Green Building

Poin 1 : Tidak melakukan penyerahan data implementasi green building sesuai form dari GBC Indonesia.

Poin 2 : Tidak terdapat penyerahan data implementasi green building dari bangunannya.

BEM 6 : Kesepatan Dalam Melakukan Fit Out

Poin 1 : Tidak memiliki surat perjanjian dengan penyewa gedung (tenant).

BEM 7 : Tingkat Kebisingan

Poin 1 : Tidak terdapat pengadaan survei suhu maupun kelembaban.

Hasil perhitungan tolak ukur kriteria dari seluruh kategori dapat dilihat pada tabel dibawah ini:

Tabel 9. Total Poin Penilaian Resto Rumah Atsiri

\begin{tabular}{|c|c|c|c|c|}
\hline \multirow{2}{*}{ Kategori } & \multicolumn{3}{|c|}{ Kriteria } & \multirow{2}{*}{ Poin } \\
\cline { 2 - 4 } & Prasyarat & Kredit & Bonus & \\
\hline ASD & - & 10 & - & $\mathbf{1 0}$ \\
\hline EEC & - & 3 & - & $\mathbf{3}$ \\
\hline WAC & - & 3 & - & $\mathbf{3}$ \\
\hline MRC & - & 7 & - & $\mathbf{7}$ \\
\hline IHC & - & 3 & - & $\mathbf{3}$ \\
\hline BEM & - & 0 & - & $\mathbf{0}$ \\
\hline $\begin{array}{c}\text { Jumlah } \\
\text { Poin }\end{array}$ & - & 26 & - & $\mathbf{2 6}$ \\
\hline
\end{tabular}

(Sumber : Analisa, 2018)

Tabel 10. Predikat Greenship New Building Rumah Atsiri

\begin{tabular}{|c|c|c|}
\hline Predikat & Minimum Poin & $\begin{array}{c}\text { Poin yang } \\
\text { didapatkan (\%) }\end{array}$ \\
\hline Platinum & 74 & 73 \\
\hline Gold & 58 & 57 \\
\hline Silver & 47 & 46 \\
\hline Bronze & 35 & 35 \\
\hline- & - & $\mathbf{2 6}$ \\
\hline
\end{tabular}

(Sumber : Analisa, 2018)

\section{KESIMPULAN}

Berdasarkan hasil pengamatan dan perhitungan sementara bangunan Resto di kawasang Rumah Atsiri Indonesia terhadap tolak ukur Greenship New Building version 1.2 dapat disimpulkan bahwa untuk saat ini gedung tersebut belum layak dinyatakan sebagai green building, karena poin yang didapatkan belum memenuhi nilai standar minimum. Bangunan Resto di 
kawasan Rumah Atsiri Indonesia hanya mendapatkan 26 poin atau dibawah predikat bronze.

Dari hasil identifikasi dengan acuan Greenship New Building Version 1.2 pada bangunan Resto di kawasan Rumah Atsiri Indonesia adalah mengupayakan memenuhi beberapa kategori dan kriteria dari tolok ukur yang sebenarnya sudah mampu didapatkan. Dengan begitu perolehan poin akan bertambah dan predikat yang didapatkan sedapat mungkin mampu menyentuh predikat bronze, atau bisa jadi menyentuh silver maupun gold.

Rekomendasi yang dapat diupayakan untuk meningkatkan poin terhadap tolok ukur ada sebagai berikut:

1. Kategori ASD 3

a. Menyediakan fasilitas halte atau transportasi umum dalam jangkauan $300 \mathrm{~m}$ dari gerbang masuk Rumah Atsiri (1 poin).

b. Menyediakan fasilitas jalur pedestrian di dalam area Rumah Atsiri untuk menuju ke transportasi umum terdekat (1 poin).

2. Kategori ASD 4

Menyediakan tempat parkir sepeda yang aman sebanyak 1 unit parkir per 20 orang pengguna gedung (1 poin).

3. Kategori WAC 3

Menggunakan seluruh air bekas pakai (grey water) yang telah didaur ulang untuk flushing (2 poin).

4. Kategori WAC 4

Memanfaaatkan teknologi baru untuk memanfaatkan air sungai yang dapat digunakan untuk keperluan irigasi, sanitasi, air bersih, dan untuk kebutuhan yang lain (2 poin).

5. Kategori IHC 2

Memasang sticker atau tanda pada gedung "Dilarang Merokok di Seluruh Area Gedung" (2 poin).

6. Kategori BEM 3

a. Mengolah secara mandiri limbah organik gedung atau dapat bekerjasama dengan pihak ketiga, sehingga dapat mengurangi dampak lingkungan (1 poin).

b. Mengolah secara mandiri limbah anorganik gedung atau dapat bekerjasama dengan pihak ketiga, sehingga dapat mengurangi dampak lingkungan (1 poin).

\section{DAFTAR PUSTAKA}

GBCl. 2013. Certification.[Online] Tersedia di: http://gbcindonesia.org/greenship/certification[ Diakses 21 Oktober 2018].

Web GBCl. 2013. Greenship NB V1.1. [Online] Tersedia di: http://gbcindonesia.org/greenship/ratingtools/download/cat view/4-greenship/5greenship-new-building[Diakses 3 Oktober 2018].

We. 2015. Greenship NB V1.2.[Online] Tersedia di:

http://gbcindonesia.org/greenship/ratingtools/download/cat view/4-greenship/5greenship-new-building[Diakses 3 Oktober 2018]

Thaib, Hiramsyah S. 2010. Ruang.[Online] Tersedia di: http://akudanruang.files.wordpress.com/2010/1 0/ruang-2-hi-res.pdf[Diakses 21 Oktober 2018].

Rumah Atsiri Indonesia, 2018. Rumah Atsiri. [Online] Tersedia di: www.rumahatsiri.com[Diakses 9 Oktober 2018]. 